\title{
Male and Female Physicians in Hospital Gynaecology Departments - Analysis of the Impact of "Feminisation" from the Viewpoint of Medical Directors
}

\author{
Ärztinnen und Ärzte in der Frauenheilkunde in den Kliniken - \\ Analyse der Auswirkungen der „Feminisierung“ aus der Perspektive der leitenden Ärzte
}

Authors

Affiliations
T. Riepen ${ }^{1}$, V. Möbus ${ }^{2}$, U. Kullmer ${ }^{3}$, H. R. Tinneberg ${ }^{4}$, K. Münstedt ${ }^{4}$

${ }^{1}$ Frauenarztpraxis, Weilburg

${ }^{2}$ Klinikum Frankfurt Höchst GmbH, Klinik für Gynäkologie, Frankfurt

${ }^{3}$ Asklepios Klinik Lich, Klinik für Gynäkologie und Geburtshilfe, Lich

${ }^{4}$ Universitätsklinikum Gießen und Marburg GmbH, Standort Gießen, Zentrum für Frauenheilkunde \& Geburtshilfe, Gießen

\section{Key words \\ - feminisation \\ - gynaecology \\ - obstetrics \\ - career planning \\ - motivation \\ Schlüsselwörter \\ - Feminisierung \\ - Frauenheilkunde \\ - Geburtshilfe \\ - Karriereplanung \\ - Motivation}

$\begin{array}{ll}\text { received } & 5.12 .2012 \\ \text { revised } & 16.12 .2012 \\ \text { accepted } & 21.12 .2012\end{array}$

Bibliography

Dol http://dx.doi.org/

10.1055/s-0032-1328185

Geburtsh Frauenheilk 2013; 73 :

53-58 @ Georg Thieme

Verlag KG Stuttgart - New York . ISSN 0016-5751

\section{Correspondence}

Prof. Dr. Karsten Münstedt Universitätsklinikum Gießen und Marburg $\mathrm{GmbH}$,

Standort Gießen

Zentrum für Frauenheilkunde

\& Geburtshilfe

Klinikstraße 33

35392 Gießen

karsten.muenstedt@

gyn.med.uni-giessen.de

\section{Abstract}

\section{$\nabla$}

Introduction: At present the topic "feminisation" in medicine, in other words the increasing number of female staff members is under heavy discussion; however, there are only few data upon the basis of which a scientific discussion can be held. The question arises as to the possibility of problems arising therefrom for the specialty gynaecology and obstetrics.

Methods: With the help of a questionnaire the directors of departments of gynaecology and obstetrics were questioned about the various aspects of the topic feminisation in gynaecology and obstetrics.

Results: Among current applications the proportion of female applicants is estimated to be $84.2 \%$. Reasons given most frequently for the feminisation in the specialty include low income, loss of face of the medical profession and the poor career chances. Among the spontaneously mentioned reasons were the increasingly female dominated image of gynaecology and the working conditions in hospitals. Whereas the taking on of surgical duties and of directing functions was less markedly desired by women than by men, the questioned directors found that male and female staff members were equally motivated to take on duties outside of their working hours or to engage in research work.

Discussion: Feminisation in medicine represents a challenge. It seems to be important to evaluate and investigate the motivation of staff members with regard to their wishes in professional life and thus to be able to offer an appropriate working environment based on the survey results.

\section{Zusammenfassung \\ $\nabla$}

Einleitung: Aktuell wird das Thema „Feminisierung“ in der Medizin, also der Zunahme des Anteils weiblicher Mitarbeiter, vielfach diskutiert, doch es gibt nur wenige Daten, auf deren Basis sich eine wissenschaftliche Diskussion führen lässt. Es stellt sich die Frage nach möglichen sich daraus ergebenden Schwierigkeiten für das Fach Frauenheilkunde und Geburtshilfe.

Methode: Mithilfe eines Erhebungsbogens wurden die Leiter von Kliniken für Gynäkologie und Geburtshilfe zu verschiedenen Aspekten rund um das Thema Feminisierung in der Gynäkologie und Geburtshilfe befragt.

Ergebnis: Bei Bewerbungen liegt der Anteil weiblicher Bewerber aktuell bei geschätzten $84,2 \%$. Als Hintergründe der Feminisierung im Fachgebiet wurden geringes Einkommen, der Ansehensverlust des Arztberufs und die schlechten Karriereaussichten am häufigsten genannt. Unter den spontan genannten Gründen wurden das zunehmend weiblich geprägte Bild des Frauenarztes und die Arbeitsbedingungen in den Kliniken als Ursachen erwähnt. Während die Übernahme operativer Tätigkeit und von Leitungsfunktionen von Frauen deutlich weniger gewünscht werden als von Männern, empfanden die Befragten weibliche und männliche Mitarbeiter gleichermaßen motiviert, Aufgaben außerhalb der Dienstzeiten zu übernehmen oder sich in der Forschung zu engagieren.

Diskussion: Die Feminisierung in der Medizin stellt eine Herausforderung dar. Das Erfassen und die Erforschung der Motivation von Mitarbeitern in Bezug auf ihre Wünsche im Arbeitsleben erscheint wichtig, um anhand der sich daraus ergebenden Befunde bedarfsgerechte Arbeitsangebote unterbreiten zu können. 


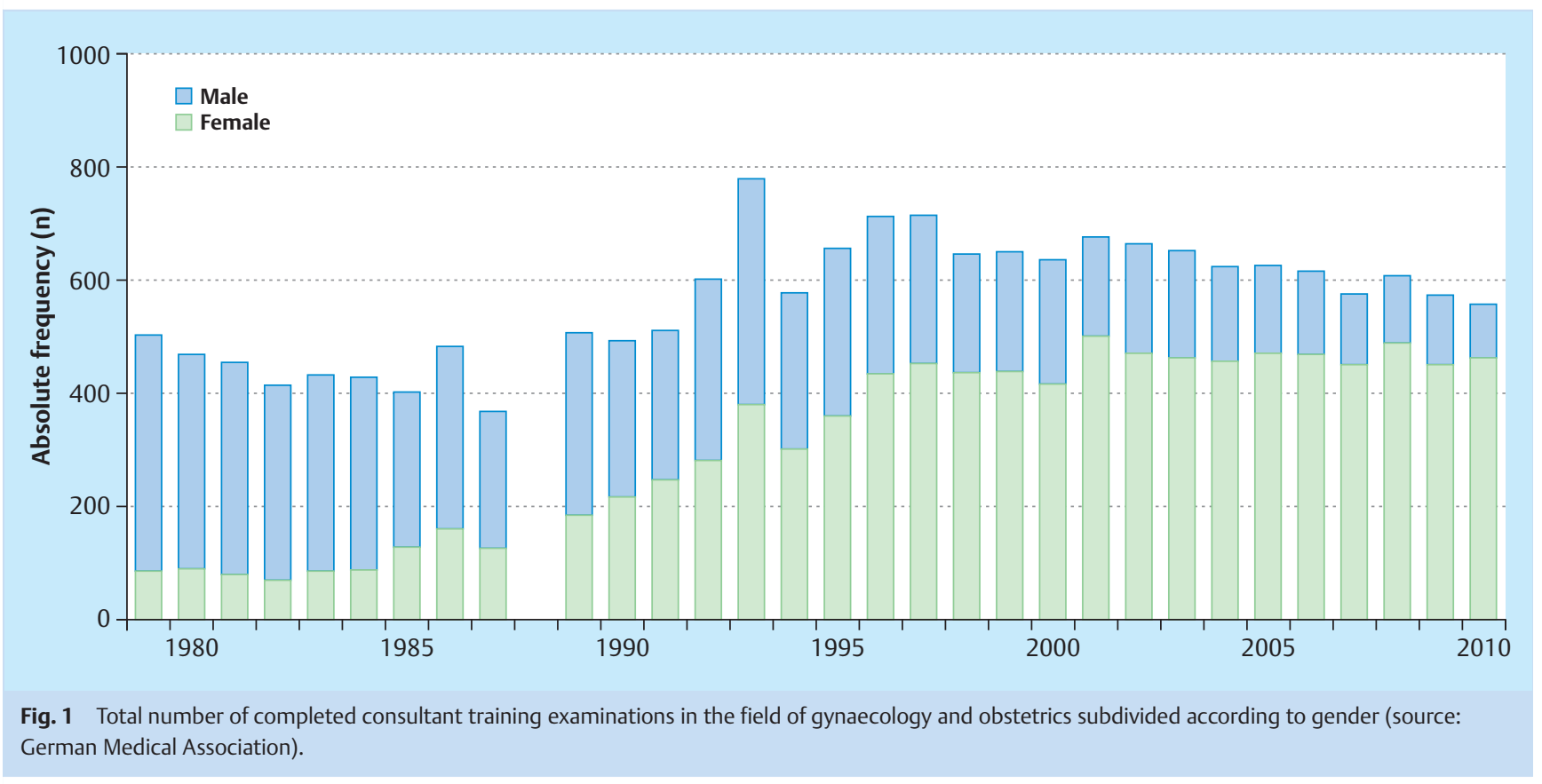

\section{Introduction \\ $\nabla$}

Even when in antique times and the early middle ages is was possible but not usual for women to study and to teach in academies, in the following centuries women only gained access to education when they entered a nunnery or convent [1]. In a few cases they became famous, like Trotula di Ruggiero, who worked in the 11 th century as a practicing physician in the medical school of Salerno and also contributed to the medical encyclopaedia Practica brevis. In some cases women even received a doctoral degree, like Marianne Theodore Charlotte v. Siebold Heidenreich, née Heiland (1788-1859), who in March 1817 in Gießen/Germany defended a doctoral thesis on "pregnancy outside the uterus and in particular about abdominal pregnancy" (http://de. wikipedia.org/wiki/Frauenstudium). In 1898 Ms. Hermine Heusler-Edenhuizen began to study medicine in Germany. In 1903 at the university gynaecological clinic she became the first woman in Germany to obtain a paid position as assistant physician. In 1909 she completed her specialist training and became the first consultant for gynaecology and obstetrics in Germany [2]. However, in general, it only became possible from 1900 onwards for women in Germany to read human medicine at universities [3].

Although men dominated in medicine in the following decades, the situation has markedly changed in the meantime. In 2006 the proportion of females among the newly enrolled medical students was $63 \%$ whereas the proportion of female professional physicians amounted to $40 \%$ [4]. This change has led to changes in the medical services as it is expected today the women carry their weight both professionally and at the same time manage their families in private life, although they most probably receive less social support and relief from their partners than their male colleagues [2]. Women also appear to have another motivation for entering the medical profession. They are less interested in money and power when they strive for a leading position, instead they rather want to create, to give themselves a reason for being and to increase their knowledge [4]. Because of these differences the careers of female physicians follow a different course. They more often take on a part-time occupation, strive less often for a doctoral degree and markedly less frequently aim to qualify as university lecturer [4].

An analysis of the German Medical Association dated 2009 revealed clear differences between the proportions of female physicians in the various specialist fields [5]. In the field of gynaecology and obstetrics the proportion of females was then $55 \%$. But, as $\bigcirc$ Fig. 1 shows, the developments towards feminisation/ feminization, as this process is called in the current literature, had started already much earlier [6].

Already in 2008 a questionnaire was sent to departments of gynaecology and obstetrics in Germany asking about gender distribution, opinions on this topic and estimations of its consequences. This revealed that even then more that $80 \%$ of the consultants and assistant physicians were female and that the proportion of women in job applications was on average about $90 \%$ [7]. The details of this questionnaire, however, were never published as an original paper. Because of the possible importance of gender changes for the field of gynaecology and obstetrics, the questionnaire survey with additional questions was repeated at the end of 2011/beginning of 2012.

\section{Material and Methods \\ $\nabla$}

\section{Questionnaire}

Based on the questionnaire of the earlier survey and the abovementioned literature, the original questionnaire with 10 questions was expanded in order to record aspects of the impact of gender changes, for example, in research work. For interested persons an example of the questionnaire is available on request to the author.

The questionnaire was sent by post at the end of 2011/beginning of 2012 to the senior physicians, head surgeons and medical directors of all 470 hospital departments of gynaecology and obstetrics in Germany [13]. The completed questionnaires could be returned by post, fax or e-mail. In March 2012 those departments 


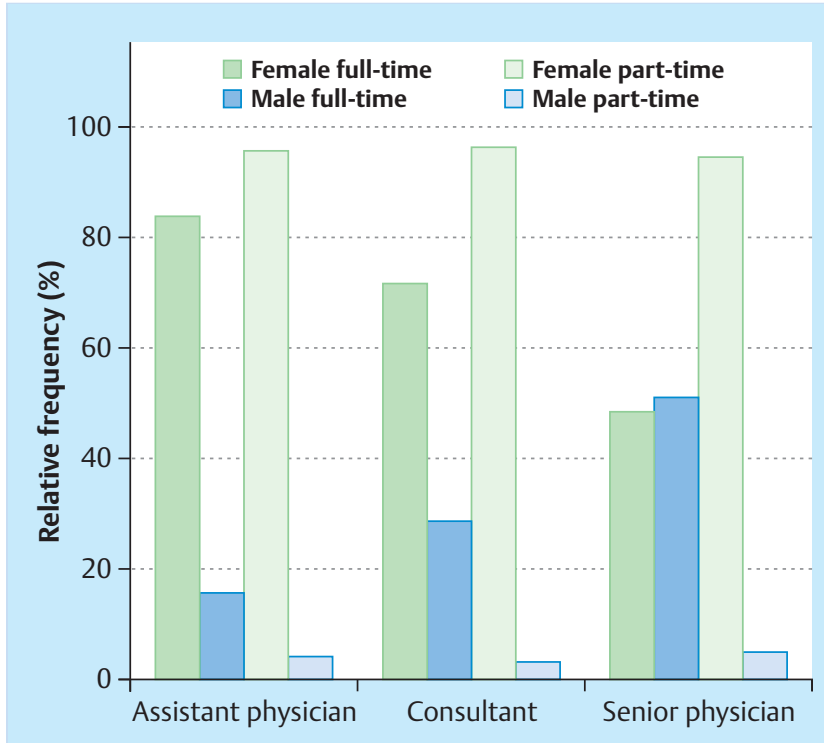

Fig. 2 Proportion of female and male staff members in part-time positions as assistant physicians, consultants and senior physicians.

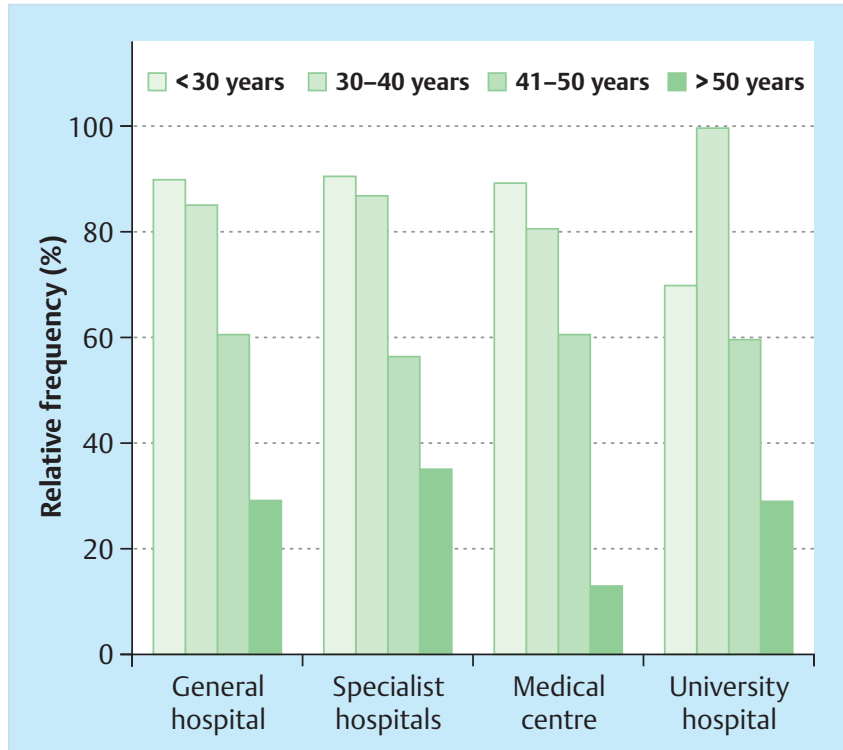

Fig. 3 Proportion of female staff members of various age groups in various hospitals. that had not yet replied were reminded about the questionnaire. The study was initiated after a positive decision had been received from the Gießen Ethics Committee (application number 83/2011).

Registering of the data and statistical analyses were performed with the help of SPSS.

\section{Results}

$\nabla$

In all, 203 questionnaires were returned and the response rate thus amounted to $43.2 \%$ (203/470). Data from 106 general hospitals, 50 specialist clinics, 31 medical centres and 13 university hospitals were evaluated. The average numbers of medical staff members in the individual hospitals were 8.8 for general hospitals, 12.5 for specialist clinics, 15.1 for medical centres and 27.6 for university hospitals.

\section{Current gender and age distributions}

- Fig. 2 shows the proportion of female and male personnel among the assistant physicians, consultants, senior and head physicians differentiated according to full-time or part-time positions. Female staff members dominated in the assistant physician, consultant and senior physician groups and especially in the part-time group. Female staff members are only under-represented in the groups of senior physicians and medical directors. Here their proportions were only $33.5 \%$, and, respectively $16.5 \%$. Further analysis revealed that male physicians in part-time positions were markedly more frequently found in the departments of medical centres or university hospitals (32 and 23\% vs. 15 and $8 \%$ in general or regional hospitals; $\mathrm{X}^{2}=8.8 ; \mathrm{df}=3$; $\mathrm{p}=0.032$ ). The results were independent of the gender of the medical director of the department or the type of hospital (ONE-WAY ANOVA). However, there is a trend that the proportion of female medical directors was higher in the general and regional hospitals in comparison to medical centres and university hospitals $\left(\mathrm{p}_{\mathrm{x}^{2}}=0.069\right)$.
- Fig. 3 shows the proportion of female staff members in the various age groups and illustrates that female staff members dominate in the younger age groups.

\section{Application situation and subjectively perceived reasons for the changes}

As far as the job application situation is concerned the proportion of applications by female physicians is estimated to amount to $84.2 \%$. The type of the hospital or the question as to whether the medical director is male or female did not play any role here (ONE-WAY ANOVA). The impression that in the past years a change in the application situation had occurred in favour of female physicians was shared by $96.5 \%$ (193/200) of the replies. - Fig. 4 shows the answers to the question: "What factors do you considered to be responsible for the fact that mostly female colleagues apply?" From the list of possible answers - that was based on the results of reports in the literature - low income, loss of face for the medical profession, and poor career changes were chosen most frequently. Since the responders also had the chance to present spontaneous answers, the spontaneous answers are distinguished by the use of colour. Here the responders mentioned the increasingly female-oriented image of gynaecologists and the working conditions in hospitals as the main reasons.

The question if the increasing proportion of female staff members has an impact on the organisation of the clinical routine was answered with yes by $75.5 \%$ (151/200). According to the estimations markedly less female staff members strive for a longterm career in the hospital or are interested in taking on a leading position in a hospital. On the other hand, female staff members are markedly more often interested in general practice work ( Fig. 5). $80.4 \%$ of the responders (160/199) found that it was, on the whole, more difficult to motivate young colleagues of both sexes to take up a long-term hospital career and/or a surgical career. The majority $(63,9 \% ; 127 / 194)$, however, found male and female colleagues to be equally motivated to take on tasks outside of working hours and this also applied to motivation to do research $(71.4 \% ; 125 / 175)$. The analysis of those who held the 


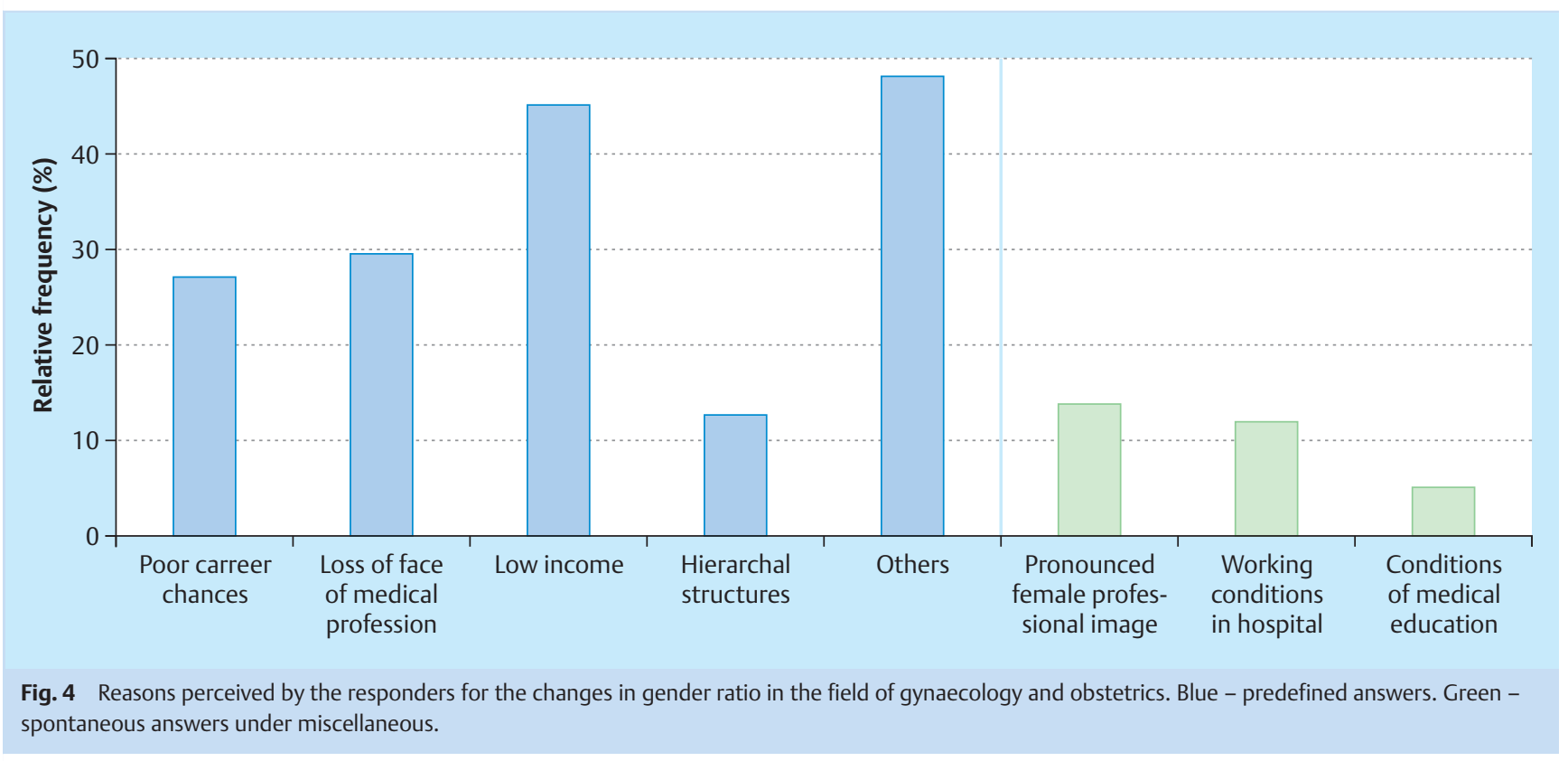

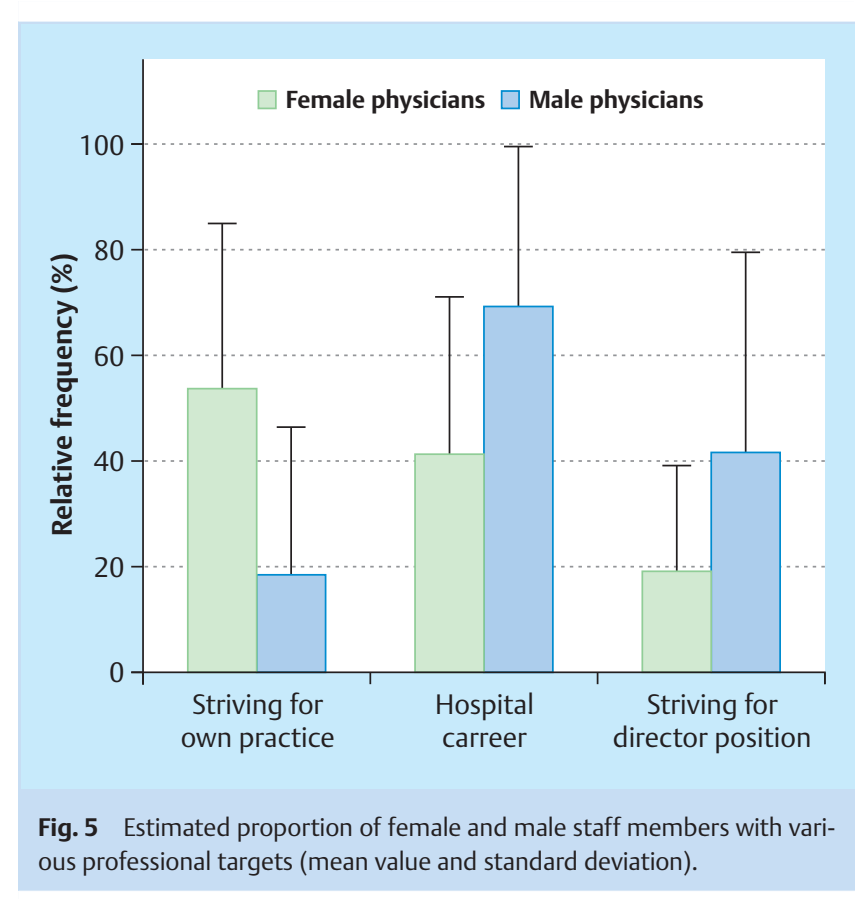

opinion that there were differences between the genders revealed that female staff members were considered to be only marginally more willing to take on tasks outside of working hours $(52.6 \%)$ whereas male staff members were considered to be more willing to participate in research $(58,9 \%)$. These estimations were also independent of the gender of the medical director of the department ( $\mathrm{X}^{2}$ test).

\section{Organisation of hospital services with full- and} part-time staff members and freelance physicians The question if the hospital services can be better organised with full-time or part-time staff members or with a balanced ratio of both was answered by the majority $(64.8 \%$; $129 / 199)$ in favour of full-time staff members. Only 5.0\% (10/199) preferred part-time staff and $30.2 \%$ (60/1999) answered in favour of a balanced ratio of full- and part-time staff members. The $\mathrm{X}^{2}$ test revealed that this estimation was independent of the type of hospital in which the medical director was employed, however, there is a trend $(p=0.060)$ that female medical directors rather preferred a balanced ratio of full- and part-time staff members. On average, a ratio of 1 part-time to 2 full-time positions was considered to be reasonable.

$30.3 \%$ (60/198) of all hospitals worked together with freelance physicians. This proportion was about equal in the various types of hospital, however, only one of the university hospitals worked together with freelance physicians. Freelance physicians are significantly more often called in for duty when the proportion of female consultants in the department is higher (ONE-WAY ANOVA; $\mathrm{F}=3.95 ; \mathrm{df}=2 ; \mathrm{p}=0.029$ ). Freelance physicians are predominantly male. On average 0.4 positions $(S D=0.8)$ in the hospitals were occupied by female freelance physicians, 1,2 positions with male freelance physicians $(\mathrm{SD}=0.9)$. Freelance physicians are mostly employed for the night shift (45.6\%; 26/57), but also often in day and night shifts (38.6\%; 22/57) and only rarely exclusively in day shifts (15.8\%; 9/57). In this point there were genderspecific differences. Male freelance physicians are mainly employed for night shift or, respectively day and night shift work (- Table 1).

\section{Discussion}

The present analysis of the employment situation for female and male physicians in gynaecology confirms the progression of feminisation in the field of gynaecology and obstetrics as mentioned in the introduction and that it is more pronounced here in comparison to other specialties. The decision in favour of the specialty is already made at the end of the studentship or even earlier and gynaecology and obstetrics as well as paediatrics are the fields for which women show the highest preference [8]. The present study confirmed the earlier analysis of 2008 [7] and re- 
Table 1 Gender-specific differences in the employment of male and female freelance physicians $\left(X^{2}=11.2 ; d f=4 ; p=0.025\right)$.

\begin{tabular}{|llcrc} 
& Day-time duty & Night-time duty & Day- and night-time duty & Total \\
Female & $4(50.0 \%)$ & $3(37.5 \%)$ & $1(12.5 \%)$ & $8(100.0 \%)$ \\
\hline Male & $4(11.4 \%)$ & $14(40.0)$ & $17(48.6 \%)$ & $35(100.0 \%)$ \\
\hline Both & $0(0.0 \%)$ & $6(60.0 \%)$ & $4(40.0 \%)$ & $10(100.0 \%)$
\end{tabular}

vealed that this process is not only positively evaluated, since these changes and the increases in the proportion of part-time staff members have made changes in general hospital organisation necessary. The majority of responders consider it to be easiest to fill the duty plans with full-time staff members. It is possible that the potential utility of part-time positions has not yet been recognised since, according to a study prepared for the Federal German Ministry for families, seniors, women and youth, the provision of part-time positions makes it easier for qualified mothers to rejoin the working population and thus counteract the general lack of qualified workers, the state also profits from this situation by way of increased income tax and contributions to social insurance services (http://www.iza.org/en/webcontent/ publications/reports/report_pdfs/iza_report_33.pdf).

Furthermore, it is interesting to note that the viewpoints of male and female medical directors in the specialty do not differ and also that the type of hospital has hardly any impact on the answers. The finding that male and female freelance physicians are assigned different duty periods poses the question if participation in night shifts or emergency service at weekends is in principle less attractive for female personnel than for male personnel. This question has not yet been addressed in research studies. Also with regard to duty times, there are different ideals between men and women. Only $40 \%$ of the female medical students after completion of their consultant training strive for a full-time position [8]. The differing professional targets of male and female assistant physicians after completion of consultant training accordingly make it difficult to attract the next generation of physicians to enter the surgical fields and thus undergo training to become highly qualified surgeons and future medical directors. According to a study by Gedrose et al. [8] the proportion of men who want to become consultants is 1.5 times higher than that of women and with regard to positions of medical director even 5.4 times higher. In contrast the proportion of women who "only" want to work as a consultant in a hospital is 3.7 times higher than that of men and, altogether, 1.3 times more women than men strive for their own practice as family doctor. In addition, women often do not seek after further qualifications for various reasons [4].

Since the coming generation of gynaecologists is almost exclusively female and the male staff members in the consultant stage are generally older, it seems highly probable that the lack of consultants in hospitals will become more critical. This holds above all for the employment of full-time staff members. As can be seen from $\odot$ Fig. 1 the absolute number of physicians who complete consultant training has continuously decreased since the end of the 1990s, which even further intensifies the problem.

A possible scenario for the future is that during the day time patients in office surgeries and outpatient departments will be managed almost exclusively by female physicians, whereas in cases of necessary inpatient operations and in the duty times of the emergency services they will rather encounter a predominantly male team [7]. Whether or not this becomes reality depends on the extent to which more female physicians can be motivated in future to take up their careers in hospitals. Since the comparatively lower income and unfavourable working times in hospitals (night duty) represent reasons to decide against a hospital career, attempts should be made to effect changes in these areas, in order to guarantee an adequate personnel situation in hospitals in the future.

One advantage of the developments leading to more female gynaecologists is that Islam-oriented population groups prefer female gynaecologists whereas most other women are more concerned about the professional competence of their physician [911]. Another positive aspect is that female gynaecologists are less often involved in legal conflicts than their male colleagues because they tend to achieve a better level of communication with their patients [12].

Since female physicians are considered to be equally willing to participate in research, the gender changes in this particular field should not have any negative impact.

In summary, the feminisation represents a major structural challenge since women are markedly less willing to take up a surgical career or to strive for higher positions than their male counterparts. This study was not designed to examine all background aspects of this complex topic. Even so, these as well as research on the motivation of staff members with regard to their professional desires in working life appear to be very important in order to be able to implement the findings of studies like this in the creation of an appropriately improved working environment with more attractive working conditions. This will surely be a most constructive means to cope with the deficit of qualified personnel.

\section{Conflict of Interest}

$\nabla$

None.

\section{References}

1 Kirchhoff A. Die akademische Frau. Gutachten herausragender Universitätsprofessoren, Fachlehrer und Schriftsteller über die Befähigung zum wissenschaftlichen Studium und Beruf. 1897. Internet: http:// archive.org/details/dieakademischef02kircgoog; last access: 30.11.2012

2 Prahm H. Hermine Heusler-Edenhuizen: Die erste deutsche Frauenärztin: Lebenserinnerungen im Kampf um den ärztlichen Beruf der Frau. 3rd edn. Leverkusen: Budrich Verlag; 2005

3 Bestmann B, Rohde V, Wellmann A et al. Berufsreport 2003: Geschlechterunterschiede im Beruf. Dtsch Arztebl 2004; 101: A-776/B-642/ C-626

4 Hibbeler B, Korzilius $H$. Arztberuf: Die Medizin wird weiblich. Dtsch Arztebl 2008; 105: A-609/B-539/C-527

5 Kopetsch T. Dem deutschen Gesundheitswesen gehen die Ärzte aus! Studie zur Altersstruktur und Arztzahlentwicklung. 5. aktualisierte und komplett überarbeitete Auflage. Berlin: Bundesärztekammer und Kassenärztliche Bundesvereinigung; 2010. Internet: http://baek.de/ downloads/Arztzahlstudie_03092010.pdf; last access: 30.11.2012

6 Bühren A, Eckert J. „Feminisierung“ der Ärzteschaft: Überschätzter Effekt. Dtsch Arztebl 2011; 108: A-1168/B-968/C-9689

7 Riepen TK, Vescia M, Möbus VJ. Zur Verteilung von weiblichen und männlichen Ärzten in der Frauenheilkunde: Eine Bestandsaufnahme. Geburtsh Frauenheilk 2008; 68: PO_Gyn_03_08 
8 Gedrose B, Wonneberger C, Jünger J et al. Haben Frauen am Ende des Medizinstudiums andere Vorstellungen über Berufstätigkeit und Arbeitszeit als ihre männlichen Kollegen? Deutsche Medizinische Wochenschrift 2012; 137: 1242-1247

9 Amir H, Tibi Y, Groutz A et al. Unpredicted gender preference of obstetricians and gynecologists by Muslim Israeli-Arab women. Patient Educ Couns 2012; 86: 259-263

10 Howell EA, Gardiner B, Concato J. Do women prefer female obstetricians? Obstet Gynecol 2002; 99: 1031-1035
11 Baethge C. Forscherinnen werden forscher. Dtsch Arztebl 2008; 105 : 507-509

12 Taragin MI, Wilczek AP, Karns ME et al. Physician demographics and the risk of medical malpractice. Am J Med 1992; 93: 537-542

13 Schütz F, Maleika A, Poeschl J et al. Partnerships between medical centres and general hospitals providing normal care standards in gynaecology and obstetrics in Germany. Geburtsh Frauenheilk 2012; 72: 922-926

Deutschsprachige Zusatzinformationen online abrufbar unter: www.thieme-connect.de/ejournals/toc/gebfra. 